\title{
CERRO PRIETO AND ITS RELATION TO THE GULF OF CALIFORNIA SPREADING CENTERS
}

\section{CERRO PRIETO Y SU CORRELACIÓN CON LOS CENTROS DE DISPERSIÓN DEL GOLFO DE CALIFORNIA}

\author{
Ana Luz Quintanilla-Montoya' \\ Francisco Suárez-Vidal ${ }^{2}$ \\ 'Facultad de Ciencias Marinas \\ Universidad Autónoma de Baja California \\ Apartado postal 453 \\ Ensenada, Baja California, México \\ ${ }^{2}$ Centro de Investigación Científica y de Educación Superior de Ensenada \\ División Ciencias de la Tierra \\ Apartado postal 2732 \\ Ensenada, Baja California, México
}

Recibido en agosto de 1995; aceptado en octubre de 1995

\begin{abstract}
The Cerro Prieto geothermal field is located in the Mexicali Valley, Baja California. Tectonically, this northern part of the Gulf of California has been classified as a spreading center, within a transitional area of oceanic to continental conditions. Thermal, geologic-tectonic and magnetic evidence has been used to postulate the existence of a heat source in the area that is associated with magmatic processes, similar to those that occur in a typical oceanic spreading center. Based on the petrography and geochemistry of the volcanic rocks obtained during the drilling of the wells in the geothermal field, the rocks were classified as: basalts, basalt-andesites, andesites and dacites. The petrogenetic model of the intrusive volcanic bodies that is proposed for the area of crustal spreading at Cerro Prieto is different from the one proposed for a typical oceanic spreading center, as is the case for the spreading centers located in the Gulf of California. This region of continental basaltic magmatism is complex due to: a) chemical composition and mineralogy of the mantle source, b) partial melting of the parent magma, c) magma segregation depth, and d) extension of the fractioned crystallization and the melting processes during the storage of the magma in the upper levels of the magmatic chamber.
\end{abstract}

Key words: Cerro Prieto, Gulf of California, spreading center, heat source.

\section{RESUMEN}

El campo geotérmico de Cerro Prieto se localiza en el valle de Mexicali, Baja California. Tectónicamente, ha sido clasificado como un centro de dispersión, ubicado en una zona de transición de condiciones oceánicas a continentales. Las evidencias térmicas, geológico-tectónicas y magnéticas han sido las bases para postular que existe una fuente de calor asociada a procesos magmáticos, similares a los que ocurren en un centro de dispersión típicamente occánico. Con base en el estudio petrográfico y geoquímico de las rocas obtenidas durante la perforación de los pozos, se encontró que éstas se clasifican como basaltos, basalto-andesitas, andesitas y dacitas. El modelo petrogenético de los cuerpos volcánicos intrusivos que se propone para la zona de dispersión de corteza en el área de Cerro Prieto, difiere con el de un típico centro de dispersión oceánico, como es el caso de los centros de dispersión 
encontrados en el golfo de California. Se presenta el modelo típico de un centro de dispersión oceánico y el modelo hipotético de dispersión para el área de Cerro Prieto. Esta región de magmatismo basáltico continental es compleja, lo cual se atribuye a: a) composición y mineralogía de la fuente en el manto, b) grado de fusión o mezcla parcial de magma primario, c) profundidad de segregación del magnla y d) extensión de la cristalización fraccionada y los procesos de mezcla del magma durante el almacenamiento de éste en los niveles superiores de la cámara magmática.

Palabras clave: Cerro Prieto, golfo de California, centro de dispersión, fuente de calor.

\section{INTRODUCTION}

Southern California (USA) and the northern part of Baja California (Mexico) form a common tectonic region that is affected by several active faults in a regional pattern, all of which belong to the San Andreas-Gulf of California system. These faults are seismically active at different levels, due to interaction between the Pacific and North American plates (fig. 1) within the Gulf of California region (Suárez-Vidal et al., 1991).

Mexicali Valley as well as the Salton Trough in California (USA) are the northernmost expressions of the Gulf of California tectonic province (Bielher et al., 1964). These crustal spreading areas (Cerro Prieto and Salton Trough) are characterized by high heat flows (Von Herzen, 1963; Lawver and Sclater, 1973; Lawver and Williams, 1979; Lee and Cohen, 1979); high microseismicity, with faulting planes that indicate normal movements of vertical dislocation (Johnson and Hadley, 1976; Gilpin and Lee, 1977; Hill et al., 1975); right lateral movement striking faults; gravity anomalies (Bielher et al., 1964; Chase et al., 1979); recent volcanism (Robinson et al., 1976); surface hydrothermal springs.

The surface volcanism of the area, as well as the name of the geothermal field are derived from the Cerro Prieto Volcano. It consists of dacite, with low andesine, hypersthene, opaque minerals and glass content. According to Elders et al. (1978) and Reed (1984), these rocks contain almost $68 \%$ of $\mathrm{SiO}$, in weight, $5.5 \%$ of $\mathrm{Na}_{2} \mathrm{O}$ and $1.7 \%$ of $\mathrm{K}_{2} \mathrm{O}$. Based upon the similarity in its major and minor chemistry, with respect to the adjacent outcrops in the area, Reed (1984) concluded that the parent magma of the volcano originated from the remelting of the basement rocks (Mesozoic). This hypothesis

\section{INTRODUCCIÓN}

El sur de California (EUA) y la parte norte de Baja California (México) forman una región común, afectada por numerosas fallas activas, a escala regional, que constituyen parte del sistema de fallas San Andrés-golfo de California. Estas fallas son sísmicamente activas en diferentes grados, siendo esta actividad el resultado de la interacción entre las placas Pacífico y Norteamérica (fig. 1) en la región del golfo de California (Suárez-Vidal et al., 1991).

El valle de Mexicali, asi como la depresión del Salton en California (EUA), son las expresiones más al norte de la provincia tectónica del golfo de Calitornia (Bielher et al., 1964). Estas áreas de dispersión (Cerro Prieto y mar del Salton) están caracterizadas por altos flujos de calor (Von Herzen, 1963; Lawver y Sclater, 1973; Lawver y Williams, 1979; Lee y Cohen, 1979), alta microsismicidad, con planos de falla que indican movimientos normales de dislocación verticales (Johnson y Hadley, 1976; Gilpin y Lee, 1977; Hill et al., 1975), así como fallamientos de rumbo con desplazamiento lateral derecho, anomalías gravimétricas (Bielher et al., 1964; Chasc et al., 1979), vulcanismo reciente (Robinson et al, 1976) y manifestaciones hidrotermales en la superficie.

El vulcanismo superficial en el área de Cerro Prieto está representado por el volcán Cerro Prieto, del cual deriva su nombre el campo geotérmico. Éste consiste de una roca dacítica, la cual contiene bajos porcentajes de andesina, hiperstena y minerales opacos, así como de vidrio. De acuerdo con Elders et al. (1978) y Reed (1984), las dacitas contienen hasta un $68 \%$ de $\mathrm{SiO}_{2}$ en peso, $5.5 \%$ de $\mathrm{Na}_{2} \mathrm{O}$ y un $1.7 \%$ de $\mathrm{K}_{2} \mathrm{O}$. Basados en la similitud de su química mayor y menor, con respecto a los afloramientos adyacentes de granodiorita, Reed 


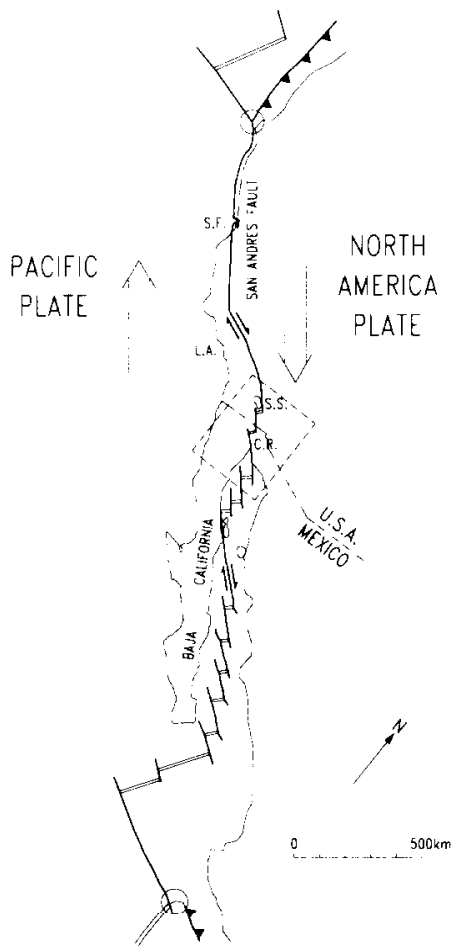

Figure 1. Tectonic framework of the border between the North American and Pacific plates: L.A., Los Angeles; S.S., Salton Sea; C.P., Cerro Prieto. (After Lachenbruch et al., 1985.)

Figura 1. Marco tectónico entre las placas Pacífico y Norteamérica: L.A., Los Ángeles; S.S., mar de Salton; C.P., Cerro Prieto. (Modificado de Lachenbruch et al., 1985.)

is also based on the $\mathrm{Sr}^{87} / \mathrm{Sr}^{86}=0.7056$ rate reported for the dacites.

Even though the Cerro Prieto Volcano is a dacite dome, there are two convincing reasons for assuming that the heat source in the field could be intrusions of basaltic origin (Elders et al., 1984). The first is that the dikes, which have been found in deep wells, are mostly diabases and the second is that basaltic intrusions are very common in a tectonic environment, known as a spreading center, associated with leaky transform faults.

Clders et al. (1984) have postulated that there is a thermal anomaly, located in a pullapart basin between the Imperial and Cerro Prieto faults. If these faults have movement rates comparable to the plate edge deformation measured in the Gulf of California, which is $5 \mathrm{~cm} / \mathrm{yr}$, an extension rate of $10 \mathrm{~cm} / \mathrm{yr}$ is
(1984) concluye que el magma padre del volcán Cerro Prieto se formó por remezcla de rocas del basamento de edad Mesozoico; esta hipótesis se basa en la razón $\mathrm{Sr}^{87} / \mathrm{Sr}^{86}=0.7056$ que reportó para las rocas dacíticas.

No obstante que el volcán Cerro Prieto es un domo de dacita, existen dos razones convincentes para poder suponer que la fuente de calor en el campo pudiera ser debido a intrusiones de origen basáltico (Elders et al, 1984). I a primera es que los diques encontrados en las perforaciones a profundidad son, en gran parte, diabasas, y la segunda es que este tipo de ambiente tectónico, conocido como de dispersión de corteza, está asociado a fallas transformadas de goteo.

Elders et al. (1984) postularon que existe una anomalia térmica, la cual está situada en una cuenca extensional (pull-apart basin) entre 


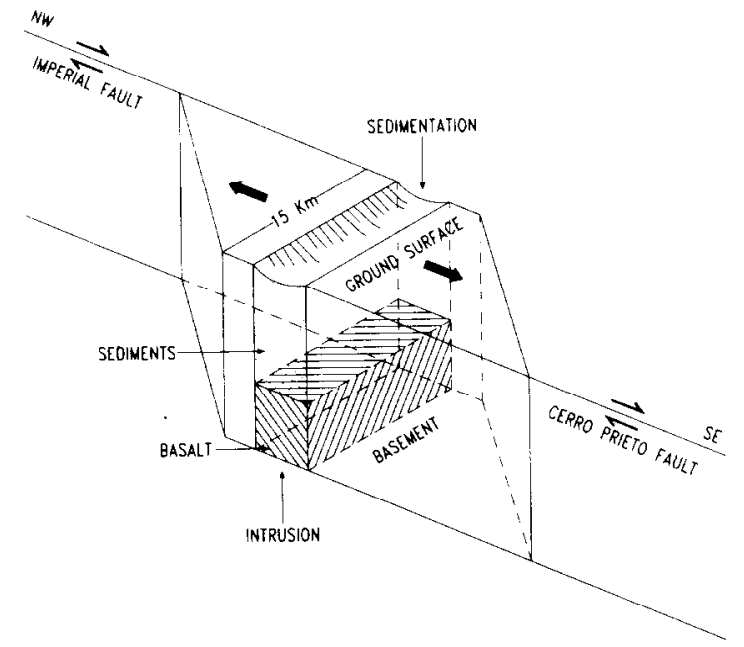

Figure 2. Development model of an extensional basin adapted to the Cerro Prieto region. The new crust area is indicated by the vertical prism within the basin. (After Elders $e t$ al., 1984.)

Figura 2. Modelo de desarrollo de una cuenca extensional adaptado para la región de Cerro Prieto. El área de corteza nueva se indica por un prisma vertical dentro de la cuenca. (Modificado de Elders et al., 1984.)

implied for the spreading center. Furthermore, if the basin could be extended in this way, it would have a displacement of $1 \mathrm{~km}$ every 10,000 years. As the distance between the Imperial and Cerro Prieto faults is around $15 \mathrm{~km}$, this requires the addition of a prism of new crust $1 \mathrm{~km}$ wide, $15 \mathrm{~km}$ long and almost $20 \mathrm{~km}$ deep every 10,000 years (fig. 2 ).

Quintanilla-Montoya and Suárez-Vidal (1994), based on magnetic data and subsurface rock samples collected from recent boreholes, proposed that the magnetic anomaly located in the geothermal field has been generated by two mafic plutonic bodies of gabroic composition, which have different dimensions at different depths and are considered part of the thermal source in the area. Based on the thermal gradient calculated, they obtained that the fusion zone is located at a depth of $11 \mathrm{~km}$.

The objective of this study is to correlate the type of volcanism present in the spreading centers of the Gulf of California with that present in the Cerro Prieto geothermal field.

\section{STUDY AREA}

The Cerro Prieto geothermal field is a system dominated by high-temperature liquid las fallas Imperial y Cerro Prieto. Si estas fallas tienen razones de movimiento comparables a la deformación de los márgenes de placa medidas en la boca del golfo de California, la cual es de $5 \mathrm{~cm} /$ año, implican una tasa de extensión de $10 \mathrm{~cm} /$ año para el centro de dispersión, y si la cuenca se extendiese de esta forma, tendrá un desplazamiento de $1 \mathrm{~km}$ cada 10,000 años. Como la distancia que separa la falla de Cerro Prieto de la falla Imperial es de alrededor de $15 \mathrm{~km}$, esto requiere añadir un prisma de corteza nueva de $1 \mathrm{~km}$ de ancho, $15 \mathrm{~km}$ de largo y hasta $20 \mathrm{~km}$ de profundidad por cada 10,000 años (fig. 2).

Con base en los datos magnéticos y los estudios de las rocas de subsuelo, QuintanillaMontoya y Suárez-Vidal (1994) proponen que la llamada anomalía magnética, localizada en el campo geotérmico, se ha generado por dos cuerpos cuyas dimensiones y profundidad son diferentes. Ambos cuerpos son de composición gabroica. Considerando el gradiente térmico calculado, se obtuvo que la zona de fusión se localiza a $11 \mathrm{~km}$ de profundidad. La presencia de estos cuerpos a profundidad es considerada parte de la fuente térmica en el campo.

El objetivo de este trabajo es correlacionar el tipo de vulcanismo que se presenta en los 


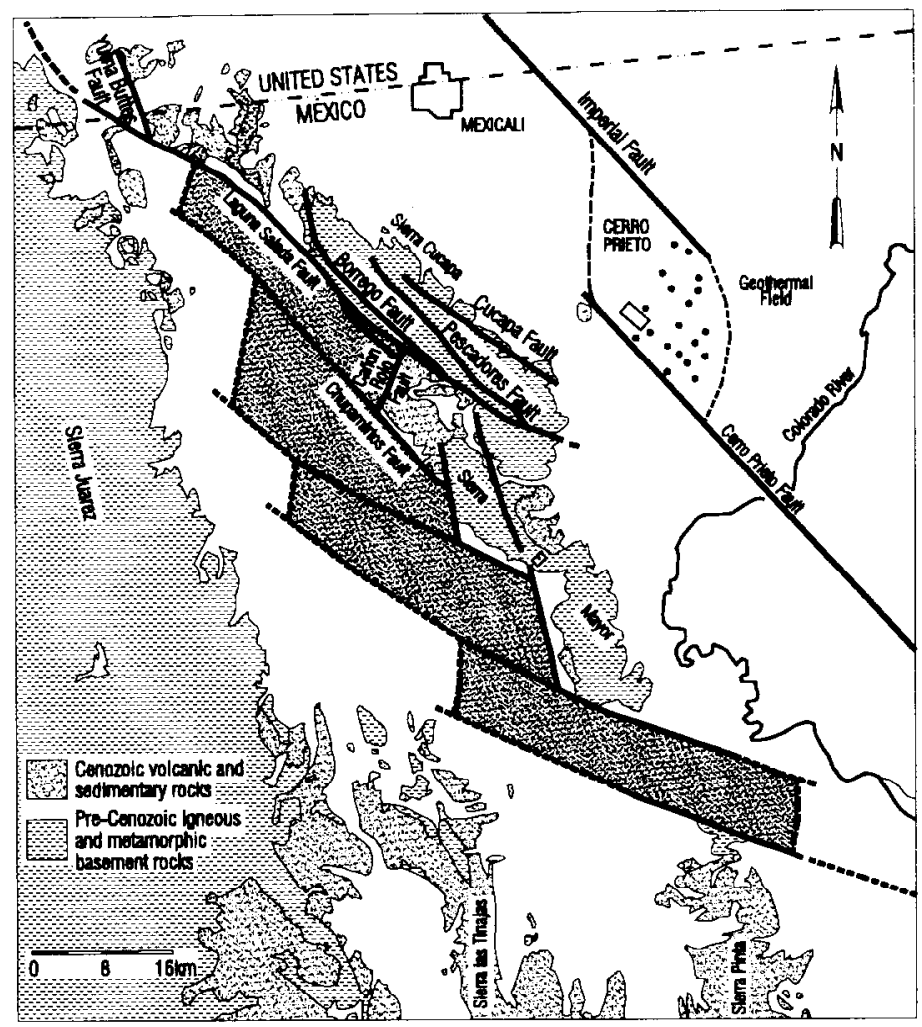

Figure 3. Map showing the location of the Cerro Prieto geothermal field and major structural and physiographic elements of the Mexicali Valley.

Figura 3. Mapa de localización del campo geotérmico de Cerro Prieto y los elementos principales estructurales y fisiográficos del valle de Mexicali.

(White, 1973), located within the Colorado River Delta, adjacent to the Sierra de los Cucapás, approximately $35 \mathrm{~km}$ to the S-SF of Mexicali, Baja California (fig. 3). The Cerro Prieto Volcano (235 m high) is located $8 \mathrm{~km}$ SE. Due to the thermal activity in Cerro Prieto, there are several hydrothermal springs at the surface. These are located SW of the field, at Volcano Lagoon, which has an area of $10 \mathrm{~km}$, several thermal springs, fumaroles and mud volcanoes.

At present, the Cerro Prieto geothermal field has approximately 125 drilled wells, with depths greater than $1 \mathrm{~km}$ and some deeper than $4 \mathrm{~km}$. It has one power plant with a production centros de dispersión del golfo de California con el vulcanismo presente en el campo geotérmico de Cerro Prieto.

\section{ÁREA DE ESTUdIO}

El campo geotérmico de Cerro Prieto es un sistema dominado por liquidos de altas temperaluras (White, 1973), situado en las cercanías del delta del río Colorado, adyacente a la sierra de los Cucapás, aproximadamente a $35 \mathrm{~km}$ al S-SE de la ciudad de Mexicali, Baja California (fig. 3); a $8 \mathrm{~km}$ al SE se encuentra el volcán de Cerro Prieto (con $235 \mathrm{~m}$ de altura). Las manifestaciones en la superficie, debido a la 
capacity of $185 \mathrm{MW}$ and two more with a capacity of $220 \mathrm{MW}$ each.

\section{METHODS}

This study is based mainly on the petrographic analysis of drilling chips obtained from five wells in the field: $M-194, M-201, M-203$, M-205 and GV-2. Barker (1979) described some typical features of these rocks: the drilling chips are less than $1 \mathrm{~cm}$ in diameter, they can be partially to totally destroyed by the drilling process, the rocks are mixed between the different depths and they are contaminated by adjacent materials, such as heavy metals, mud additives or rock material that has no relation to the rocks from the bottom.

Thin slides of the fresh rock samples selected were prepared for the petrographic analysis. Approximately 450 rock sections were analyzed to determine the mineralogy and textural features. Four samples from the deepest wells were sent for X-ray diffraction analysis to identify the clay minerals that were impossible to determine from microscopic analysis. The most characteristic rocks were sent to the University of Utah Research Institute Laboratory in the USA to determine the whole rock chemistry as well as trace elements.

The compositional variation diagrams were plotted by means of the least squares method in order to correlate the regional data (East Pacific Rise, Guaymas Basin, Isla Tortuga, Salton Trough and Imperial Valley in California, USA) with the Cerro Prieto volcanism.

\section{RESULTS AND DISCUSSION}

According to the classification of volcanic rocks of Cox et al. (1979), the sub-basement rocks recovered from the deepest wells are: basalts, basalt-andesites, andesites and dacites (fig. 4). This is based upon the whole rock chemistry and trace elements shown in table 1 .

Lithology, mineralogy and texture are described briefly.

\section{Dacites}

The $\mathrm{SiO}_{2}$ content in the group ranges from 64.20 to $65.50 \%$. The textures observed are actividad termal en Cerro Prieto, están situadas al SO del campo, en la laguna Volcano, en un área de $10 \mathrm{~km}^{2}$ con numerosos manantiales termales, fumarolas y volcanes de lodo.

En el presente, el campo geotérmico de Cerro Prieto consta aproximadamente de 125 pozos con profundidades mayores a $1 \mathrm{~km}$. algunos con más de $4 \mathrm{~km}$ de profundidad. Actualmente, se tiene una planta con poder de producción de $185 \mathrm{MW}$ y dos con capacidades de $220 \mathrm{MW}$ cada una.

\section{MÉTODO DE ESTUDIO}

El presente estudio está basado en gran parte en el análisis petrográfico de muestras de canal obtenidas durante la perforación de cinco pozos profundos: M-194, M-201, M-203, M-205 y GV-2. Barker (1979) describe algunas características típicas de las muestras: las muestras son pequeñas, generalmente tienen menos de $1 \mathrm{~cm}$ de diámetro; las muestras son cortadas en sesgo y la calidad de éstas varía desde estar parcial hasta totalmente destruidas; existe mezcla entre las rocas durante la circulación del lodo de perforación; existe contaminación de las muestras con otro material ajeno a la roca del fondo del pozo.

Para la elaboración del análisis petrológico se usó la siguiente metodología. Se seleccionaron muestras de canal frescas y se elaboraron láminas delgadas para su análisis petrográfico (aproximadamente 450 secciones de rocas fueron analizadas para determinar su mineralogía y rasgos texturales). Se analizaron cuatro muestras de roca por el método de difracción de rayos $\mathrm{X}$ con el fin de identificar minerales arcillosos de origen secundario, los cuales fue imposible identificar mediante el análisis microscópico. Se seleccionaron muestras de cortes litológicos que fueron enviados al laboratorio del Instituto de Investigaciones de la Universidad de Utah, EUA, en donde se les practicó análisis de roca total (óxidos mayores y elementos traza).

Se utilizó la técnica de análisis de regresión lineal, por el método de mínimos cuadrados, para elaborar diagramas de variación composicional y así poder correlacionar los datos de Cerro Prieto con los que ya se tienen a nivel regional (vulcanismo presente en la dorsal del 


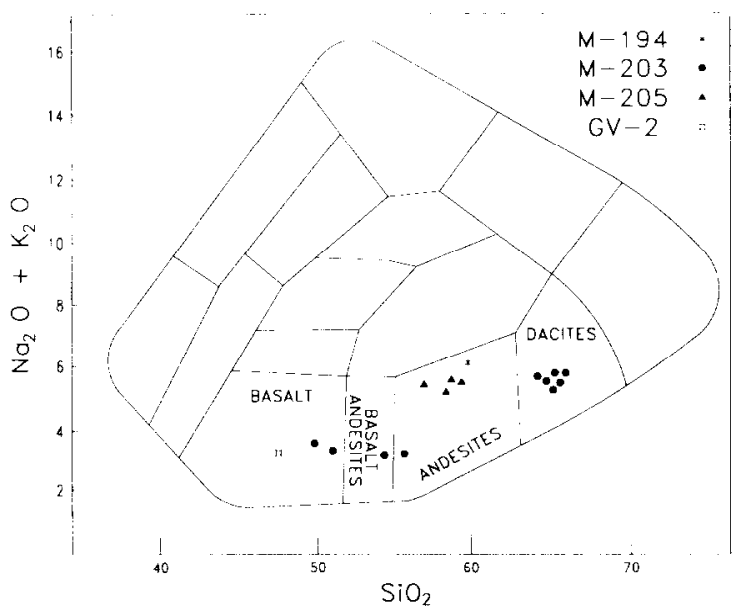

Figure 4. Chemical classification of the rocks studied according to Cox et al. (1979).

Figura 4. Clasificación química de las rocas estudiadas de acuerdo con Cox et al. (1979).

mainly aphanitic, aphyric, porphyritic and some show directional fabric or flow structures. The plagioclase composition is $\mathrm{An}_{50}$, with extinction angles of $28-30^{\circ}$. Some potassic feldspars and quartz crystals were found, with undulatory extinction. The Fe-Ti oxides are represented principally by ilmenite and magnetite and glass gives the typical interstitial texture.

As a result of secondary mineralization, there is epidote (in the form of columnar aggregates), chlorites and sericites stemming from feldspar alteration. Evidence of devitrification processes is shown in the spherulitic textures.

\section{Basalt-andesites and andesites}

$\mathrm{SiO}_{2}$ content varies from 57.40 to $59 \%$ in weight (table 1, fig. 4). Texturally, these rocks are porphyritic, with prominent phenocrystals of plagioclases and mafic minerals that are included in a pilotaxitic matrix. Other textures, such as variolitic and some ophitic, were also observed. Feldspar alignment in these rocks (trachytic texture) is a common characteristic that can be attributed to the flow textures produced when the intrusion of these rocks took place in the sedimentary sequences in the field.

Plagioclase comprise more than $75 \%$ of the phenocryst and present several patched
Pacífico Este, cuenca de Guaymas, isla Tortuga y mar de Salton en el valle Imperial, California, EUA).

\section{RESULTADOS Y DISCUSIÓN}

Con base en la clasificación propuesta por Cox et al. (1979) para rocas volcánicas, las rocas de subsuelo recuperadas de los pozos profundos resultaron ser: basaltos, basaltoandesitas, andesitas y dacitas (fig. 4), de acuerdo con los resultados del análisis químico de elementos mayores (tabla 1).

La litología mineralogía y textura de las rocas se describen a continuación.

\section{Dacitas}

El contenido de $\mathrm{SiO}_{2}$ varía desde 64.20 hasta $65.50 \%$ en peso. Texturalmente, estas rocas presentan texturas afaníticas o vítreas afiricas, algunas porfiríticas, y muestran fábrica direccional o estructuras de flujo. La composición de plagioclasas es de $\mathrm{An}_{\mathbf{s}_{1 /}}$ con sus respectivos ángulos de extinción de $28-30^{\circ}$. En moda también se encontraron algunos cristales de cuarzo y feldespatos potásicos con extinción ondulatoria. Los óxidos de $\mathrm{Fe}$ y $\mathrm{Ti}$ se ven representados principalmente por ilmenita $y$ 
Table 1. Chemical analysis of the volcanic rocks of Cerro Prieto: major oxides (100\% in weight); trace elements (ppm).

Tabla 1. Análisis químico de las rocas volcánicas de Cierro Prieto: óxidos mayores (100\% en peso); elementos traza (ppm).

\begin{tabular}{|c|c|c|c|c|c|c|c|c|c|c|c|c|c|c|c|c|}
\hline & \multicolumn{16}{|c|}{ Well and depth } \\
\hline & M-194 & $\mathrm{M}-203$ & M-203 & M-203 & M-203 & M-203 & M-203 & M-203 & $\mathrm{M}-203$ & M-203 & M-203 & M-205 & M-205 & M-205 & $M-205$ & GV2 \\
\hline & $2553 \mathrm{~m}$ & $3327 \mathrm{~m}$ & $3336 \mathrm{~m}$ & $3351 \mathrm{~m}$ & $3354 \mathrm{~m}$ & $3921 \mathrm{~m}$ & $3927 \mathrm{~m}$ & $3930 \mathrm{~m}$ & $3942 \mathrm{~m}$ & $3957 \mathrm{~m}$ & $3969 \mathrm{~m}$ & $1795 \mathrm{~m}$ & $2360 \mathrm{~m}$ & $2382 \mathrm{~m}$ & $2754 \mathrm{~m}$ & $3020 \mathrm{~m}$ \\
\hline $\mathrm{SiO}_{2}$ & 59.63 & 50.10 & 51.60 & 54.40 & 50.59 & 64.40 & 64.20 & 64.60 & 64.93 & 65.50 & 64.50 & 58.30 & 58.90 & 58.40 & 57.40 & 47.80 \\
\hline $\mathrm{TiO}_{2}$ & 1.79 & 2.11 & 2.08 & 2.02 & 2.29 & 0.773 & 0.771 & 0.778 & 0.780 & 0.745 & 0.834 & 1.79 & 1.76 & 1.74 & 1.79 & 1.14 \\
\hline $\mathrm{Al}_{2} \mathrm{O}_{3}$ & 14.49 & 14.76 & 14.58 & 13.16 & 13.97 & 15.60 & 15.87 & 15.84 & 15.63 & 15.38 & 15.38 & 15.25 & 14.95 & 14.89 & 15.20 & 17.24 \\
\hline $\mathrm{Fe}_{2} \mathrm{O}_{3}$ & 2.50 & 10.35 & 4.49 & 3.42 & 4.61 & 2.61 & 2.57 & 2.88 & 2.44 & 2.26 & 2.55 & 4.44 & 3.89 & 3.53 & 4.41 & 4.47 \\
\hline $\mathrm{FeO}$ & 5.60 & & 5.05 & 6.15 & 6.38 & 3.79 & 3.96 & 3.59 & 3.97 & 3.74 & 3.58 & 5.03 & 5.52 & 5.75 & 4.99 & 5.19 \\
\hline $\mathrm{AgO}$ & 2.24 & 5.48 & 5.48 & 5.33 & 5.48 & 0.988 & 0.996 & 0.985 & 1.02 & 0.962 & 1.33 & 2.36 & 2.32 & 2.36 & 2.38 & 7.77 \\
\hline $\mathrm{CaO}$ & 6.08 & 8.78 & 8.43 & 8.41 & 8.98 & 4.55 & 4.59 & 4.56 & 4. & 4.31 & 4.74 & 5.68 & 5.55 & 5.54 & 5.68 & 9.58 \\
\hline $\mathrm{a}_{2} \mathrm{O}$ & 2.63 & 2.79 & 2.82 & 2.56 & 2.68 & 4.45 & 4.47 & 4.54 & 4.60 & 4.64 & 4.43 & 4.65 & 4.72 & 4.71 & 4.68 & 2.95 \\
\hline $\mathrm{K}_{2} \mathrm{O}$ & 3.40 & 0.935 & 0.920 & 0.572 & 0.686 & 1.24 & 1.40 & 1.26 & 1.17 & 1.32 & 1.08 & 0.828 & 0.815 & 0.750 & 0.833 & 0.131 \\
\hline $\mathrm{MnO}$ & 0.133 & 0.180 & 0.173 & 0.178 & 0.197 & 0.088 & 0.084 & 84 & 0.095 & 0.080 & 0.099 & 0.170 & 0.167 & 0.166 & 0.163 & 0.156 \\
\hline $\mathrm{P}_{2} \mathrm{O}_{3}$ & 0.334 & 0.262 & 0.267 & 0.240 & 0.265 & 0.263 & 0.259 & 0.259 & 0.263 & 0.252 & 0.250 & 0.420 & 0.414 & 0.412 & 0.414 & 0.098 \\
\hline $\mathrm{Ba}_{2} \mathrm{O}$ & 0.121 & 0.013 & 0.015 & 0.034 & 0.013 & 0.079 & 0.058 & 0.060 & 0.053 & 0.056 & 0.051 & 0.051 & 0.045 & 0.048 & 0.053 & 0.156 \\
\hline SI & 356 & 257 & 269 & 207 & 213 & 412 & 416 & 413 & 385 & 364 & 364 & 280 & 252 & 272 & 283 & 226 \\
\hline Co & 46 & 31 & 164 & 61 & 47 & 65 & 61 & 64 & 55 & 51 & 55 & 44 & 201 & 60 & 46 & 44 \\
\hline $\mathrm{Cr}$ & 8 & 130 & 141 & 115 & 103 & $<2.0$ & $<2.0$ & 14 & 11 & 12 & 9 & $<2.0$ & 43 & 33 & 5 & 257 \\
\hline $\mathrm{Cu}$ & 83 & 47 & 48 & 49 & 54 & 62 & 28 & 22 & 161 & 238 & 276 & 25 & 25 & 27 & 25 & 77 \\
\hline $\mathrm{Ni}$ & 10 & 58 & 60 & 47 & 46 & $<5.0$ & 11 & 12 & 7 & 11 & 6 & 5 & 9 & 8 & 8 & 139 \\
\hline $\mathrm{b}$ & $<10$ & $<10$ & $<10$ & $<10$ & $<10$ & $<10$ & $<10$ & $<10$ & $<10$ & $<10$ & $<10$ & $<10$ & $<10$ & $<10$ & $<10$ & 394 \\
\hline V & $<250$ & $<250$ & $<250$ & $<250$ & $<250$ & $<250$ & $<250$ & $<250$ & $<250$ & $<250$ & $<250$ & $<250$ & $<250$ & $<250$ & $<250$ & $<250$ \\
\hline U & $<2500$ & $<2500$ & $<2500$ & $<2500$ & $<2500$ & $<2500$ & $<2500$ & $<2500$ & $<2500$ & $<2500$ & $<2500$ & $<2500$ & $<2500$ & $<2500$ & $<2500$ & $<2500$ \\
\hline $\mathrm{Zr}$ & 239 & 158 & 163 & 157 & 176 & 341 & 336 & 318 & 316 & 326 & 286 & 289 & 298 & 290 & 294 & 159 \\
\hline $\mathrm{Zn}$ & 82 & 91 & 111 & 90 & 96 & 126 & 121 & 116 & 145 & 1467 & 255 & 126 & 387 & 230 & 126 & 82 \\
\hline Sn & 6 & 8 & 5 & 16 & $<5.0$ & 13 & $<5.0$ & $<5.0$ & $<5.0$ & $<5.0$ & $<5.0$ & $<5.0$ & 9 & $<5.0$ & $<5.0$ & $<5.0$ \\
\hline $\mathrm{Li}$ & 9 & 16 & 16 & 9 & 10 & 9 & 8 & 9 & 7 & 8 & 7 & 15 & 13 & 12 & 14 & 26 \\
\hline $\mathrm{Be}$ & 2.4 & 1.9 & 1.9 & 1.8 & 1.9 & 2.5 & 2.6 & 2.5 & 2.5 & 2.5 & 2.4 & 2.2 & 2.3 & 2.2 & 2.2 & 1.4 \\
\hline $\mathrm{La}$ & 48 & 26 & 26 & 25 & 26 & 39 & 39 & 40 & 39 & 38 & 37 & 32 & 34 & 33 & 33 & 18 \\
\hline $\mathrm{Ce}$ & 63 & 19 & 21 & 21 & 23 & 50 & 50 & 52 & 49 & 46 & 44 & 33 & 39 & 35 & 33 & $<10.0$ \\
\hline Th & $<150$ & $<150$ & $<150$ & $<150$ & $<150$ & $<150$ & $<150$ & $<150$ & $<150$ & $<150$ & $<150$ & $<150$ & $<150$ & $<150$ & $<150$ & $<150$ \\
\hline
\end{tabular}


inclusions. Their chemical composition is $\mathrm{An}_{40.77}$. Normal zonation was also observed in the crystals.

Remelting textures are common characteristics in these rocks and were observed as small holes that have been filled by matrix minerals and by glass.

The presence of small olivine grains shows the transitional step from basalt-andesite rocks, or transitionals, to basaltic rocks (tholeiitic). They can only be distinguished by the higher $\mathrm{SiO}_{2}$ content of $52 \%$ and, therefore, a higher normative quartz content. The term basaltandesites that is used for these rocks is due to the completely gradational transition between the two classes.

Pyroxenes are found in more stable phases than olivines, due to the presence of corona (reaction rim) textures in the olivine. This indicates an incomplete reaction of the olivines with the melt or fluid, to produce an external zone (reaction rim) that is represented by a pyroxene or amphibole corona (Williams et al., 1982). As a result of the devitrification processes, there are some spherulitic and variolitic textures. According to Williams et al. (1982), these are characteristic textures of sills or dikes.

The remelting texture mentioned above is present mainly in calcic feldspars, which is per se a thermal-composition disequilibrium texture during crystallization. This is caused by minerals beginning to melt or react and the resulting melt filling up the interior of the holes observed in plagioclases. This can be considered as evidence of magmatic mixing with common origins. Other remelting textures are seen in corroded crystals, plagioclase zonation and probably in the partial conversion of hornblende to pyroxenes, and from hornblende to oxihornblende, resulting in iron oxides.

\section{Basaltic rocks}

The $\mathrm{SiO}_{2}$ content in these rocks ranges from 47.80 to $51.60 \%$ by weight. These rocks fall within the basalt classification (Cox et al., 1979) to be tholeiitic and transitional or subalkaline basalts (fig. 5).

The petrographic features of this lithology are: holocrystalline rocks, with predominant in- magnetita, y el vidrio da la típica textura intersticial a estas rocas.

Como resultado de la mineralización secundaria existen epidota (en forma de agregados columnares), cloritas y sericitas provenientes principalmente de la alteración de feldespatos. Hay evidencias de procesos de devitrificación, lo cual se muestra en las texturas esferulíticas.

\section{Rocas andesíticas y basalto andesíticas}

El contenido de $\mathrm{SiO}_{2}$ en estas rocas varía desde 57.40 hasta $59 \%$ en peso (tabla 1, fig. 4). Texturalmente, las rocas son porfiriticas, con prominentes fenocristales tanto de plagioclasas como de minerales ferromagnesianos que se encuentran embebidos en una matriz pilotaxítica. Otras texturas, tales como variolíticas y algunas ofíticas, también fueron observadas. El alineamiento de feldespatos en estas rocas (textura traquítica) es una caracteristica común de estas rocas, lo cual puede atribuirse a que estas texturas en flujo fueron producidas en el momento de intrusión de las rocas dentro de las secuencias sedimentarias en el campo.

Las plagioclasas comprenden más del $75 \%$ de los fenocristales y presentan numerosas inclusiones en forma de parche. La composición de éstas es $\mathrm{An}_{4(1)-71)}$. La zonación presente en los cristales es de tipo normal.

La textura de remezcla es una caracteristica común de estas rocas y se ha observado como pequeñas oquedades que han sido rellenadas por minerales provenientes de la matriz y por vidrio.

La presencia de pequeños granos de olivino en algunas rocas marcan la característica de ocurrencia de las rocas llamadas basaltoandesitas o transicionales a rocas basálticas (tholeiitas). Éstas se distinguen únicamente por tener un contenido mayor de $52 \%$ de $\mathrm{SiO}_{2} \mathrm{y}$, por tanto, mayor contenido de cuarzo normativo. Son las rocas generalmente designadas con el nombre de basalto-andesitas debido a su transición entre las dos clases, la cual es completamente gradacional.

Los piroxenos se encuentran en fases más estables que los olivinos debido a la presencia de texturas de corona en los últimos, lo cual indica una reacción incompleta del mineral 


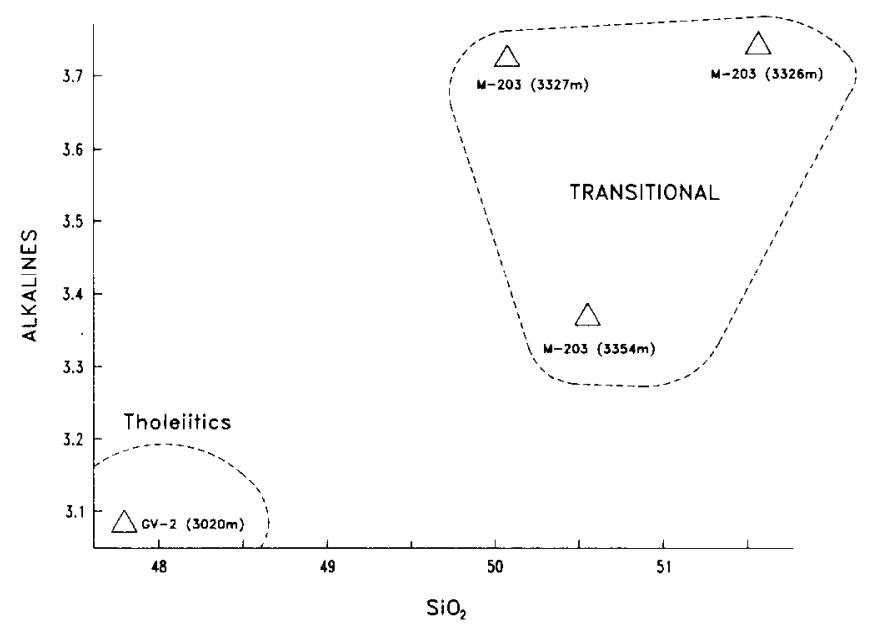

Figure 5. Chemical classification of the basalts studied.

Figura 5. Clasificación química de los basaltos estudiados.

tergranular, porphyritic, ophitic and subophitic textures, even when some glomeroporphyritic textures were observed.

The dominant mineralogy of these rocks is constituted by calcic feldspars and pyroxenes. The composition of the first is $\mathrm{An}_{50-70}$ and sizes are as long as $1.5 \mathrm{~mm}$. Remelting textures are also very common, and are mainly seen in plagioclases. Pyroxenes are augite clinopyroxenes. They are very abundant as phenocrysts, whereas hyperstenes are present, but in less abundance. Based on the X-ray diffraction studies, olivines are mainly forsterite and there are three main groups of opaque minerals: magnetites, titano-magnetite and iron sulfides as pyrite and pyrrothite, reported as associated secondary mineralization by the Comisión Federal de Electricidad (CFE).

Secondary mineralization is primarily represented by carbonates (fibrous calcite resulting from hydrothermal alteration). Chlorites and sericites appeared to be secondary products of feldspars and epidotes; kaolinite and clay minerals were also observed. The clay minerals were determined as chlorite-montmorillonite aggregates from the X-ray diffraction analysis. Other minerals such as nontronite or possibly saponite were found; however, proportion determination is difficult, due to the presence of the chlorite-montmorillonite aggregate. (olivino) con la mezcla o fluido, para producir una zona externa (anillo de reacción) que se ve representada por una corona de piroxeno o anfibol (Williams et al., 1982). Como producto de procesos de desvitrificación se presentan texturas de corona, esferulíticas y variolíticas. De acuerdo con Williams et al. (1982), estas texturas son típicas de flujos y márgenes de diques o sills.

La textura de remezcla mencionada con anterioridad se presenta básicamente en los feldespatos cálcicos, lo cual es en sí una evidencia del desequilibrio térmico-composicional durante la cristalización. Este desequilibrio causa que dichos minerales comiencen a mezclarse o a reaccionar y esta mezcla rellene el interior de las oquedades observadas en las plagioclasas. Se puede considerar lo anterior por ser una evidencia de la mezcla de magmas de origen común. Otras texturas de mezcla son los cristales corroídos, zonación en plagioclasas y probablemente conversión parcial de hornblenda a piroxenos, y de hornblenda a oxihornblenda, hasta dar como resultado óxidos de ficrro.

\section{Rocas basálticas}

El $\mathrm{SiO}_{2}$ varía en estas rocas desde 47.80 hasta $51.60 \%$ en peso. Estas rocas caen dentro de la clasificación de basaltos (Cox et al., 1979) 
The geochemical information on rocks from spreading centers in the Gulf of California was taken from articles published for: Isla Tortuga (Batiza, 1978). East Pacific Rise (Lonsdale and Spiess. 1979), Guaymas Basin (Perfit et al., 1982), Salton Trough in California (Elders et al., 1978). Quaternary volcanism present in the Salton Sea geothermal ficld (Robinson et al, 1976) and the Cerro Prieto Volcano (Reed, 1984) (tig. 1).

The correlation of geochemical data for the entire area (Gulf of California, Cerro Prieto and Salton Trough) is not simple, since the data originate from different sources. Furthermore, in the case of the subsurface rocks recovered from the geothermal wells, their whole rock chemistry has been altered (Browne, 1977). There are some effects of alteration in Gulf of California basalts that indicate an enrichment of $\mathrm{Fe}, \mathrm{Ti}, \mathrm{K}$, and a loss in $\mathrm{Mg}, \mathrm{Ca}, \mathrm{Si}$ (Terrel et al., 1979, in Perfit et al., 1982). These effects of alteration can produce errors in the rock correlation.

The diagram of compositional variation (fig. 6) shows that the rocks within the regional pattern (Gulf of California, Cerro Prieto and Salton Sea) can be classified according to Cox et al. (1979) as: a) basalts and basalt-andesites, b) andesites, c) dacites and d) rhyolites.

The alkalinity graphs (figs. 6, 7, 8) show the different types of volcanism that are present in the region. A linear tendency from basaltic rocks can be observed, in which rocks from Isla Tortuga, Guaymas Basin, the East Pacific Rise and some subsurface volcanic rocks from Cerro Prieto and the Salton Trough can be included (the $\mathrm{SiO}_{2}$ content varies from 45 to $55 \%$ in weight): andesite and basalt-andesite transitional rocks occur mainly in the Cerro Prieto geothermal field $\left(\mathrm{SiO}_{2}\right.$ content varies from 55 to $65 \%$ ); continental environment rocks such as dacites and rhyolites occur at Cerro Prieto (subsurface samples, as well as the surface expression observed in the Cerro Prieto Volcano and the Obsidian Buttes of the Salton Trough).

Figures 8 to 12 show the graphs for the volcanic rocks of Cerro Prieto as well as for others of the regional pattern. It can be observed that the $\mathrm{CaO}$ (fig. 8), $\mathrm{FeO}$ (fig. 9), $\mathrm{MgO}$ (fig. 10) and $\mathrm{TiO}_{2}$ (fig. 12) oxides maintain a similar en la clase tholeiticos y transicionales o subalcalinos (fig. 5).

Los aspectos petrográticos en esta litología son: rocas holocristalinas con texturas intergranulares. porfiriticas, ofiticas y subofiticas predominantemente, aunque en algunas se observaron también glomeroportiríticas.

La mincralogía dominante en estas rocas está constituida por feldespatos cálcicos y piroxenos. Los primeros tienen una composición $A n_{50-70}$ y alcanzan tamaños hasta de $1.5 \mathrm{~mm}$ de largo. Una vez más, las texturas de remezcla son características de estas rocas y se observan principalmente en los feldespatos cálcicos. Los piroxenos son clinopiroxenos del tipo augita. Son abundantes como fenocristales, a diferencia de algunos hiperstenos que se presentan en menor abundancia. Con base en el método de difracción de rayos $X$, el olivino resultó ser del tipo forsterita y existen tres grupos principales de minerales opacos presentes en las rocas: magnetita, titano-magnetita y sulfuros de fierro como pirita y pirrotita, los cuales son reportados por la Comisión Federal de Electricidad (CFE) como mineralización asociada.

La mineralización secundaria está básicamente representada por carbonatos; fue común observar calcita fibrosa, además de haberse observado la presencia de cloritas y sericitas, como productos secundarios de feldespatos, epidotas, minerales arcillosos y caolinitas. Las muestras que presentaron minerales arcillosos fueron sometidas al análisis de difracción de rayos X para determinar la composición, resultando ser agregados de clorita-montmorilonita, aunque no se determinaron sus respectivas proporciones debido a la presencia de esmectita. También se encontraron minerales parecidos a nontronita o posiblemente saponita, cuya determinación de proporciones es dificil debido a la presencia del mismo agregado de clorita-montmorilonita.

$\mathrm{La}$ información geoquímica de las rocas presentes en el golfo de California fue tomada de trabajos publicados en las siguientes regiones (ver fig. 1): isla Tortuga (Batiza, 1978), dorsal del Pacifico Este (Lonsdale y Spiess, 1979), cuenca de Guaymas (Perfit et al., 1982), la depresión del Salton en California (Elders et al. 1978), vulcanismo Cuaternario presente en 


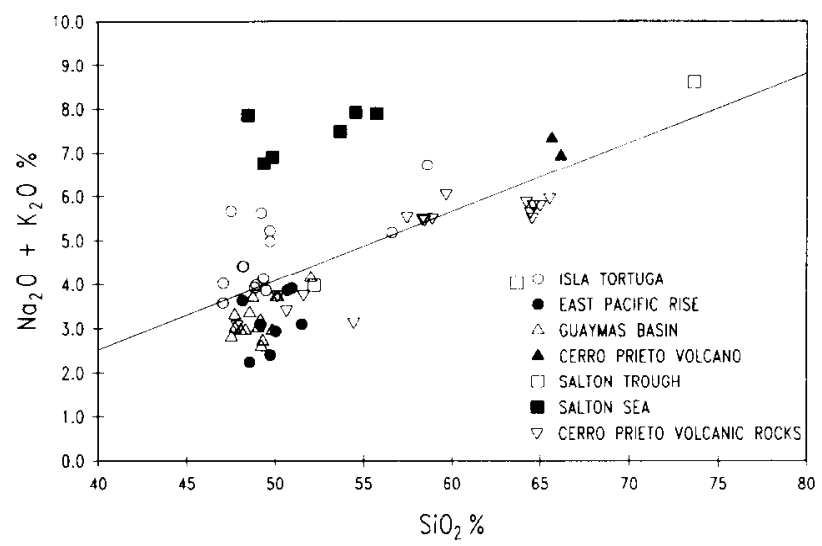

Figure 6. Alkalinity diagram $\left(\mathrm{SiO}_{2}\right.$ vs $\left.\mathrm{Na}_{2} \mathrm{O}+\mathrm{K}_{2} \mathrm{O}\right)$.

Figura 6. Diagrama de alcalinidad $\left(\mathrm{SiO}_{2} v s \mathrm{Na}_{2} \mathrm{O}+\mathrm{K}_{2} \mathrm{O}\right)$.

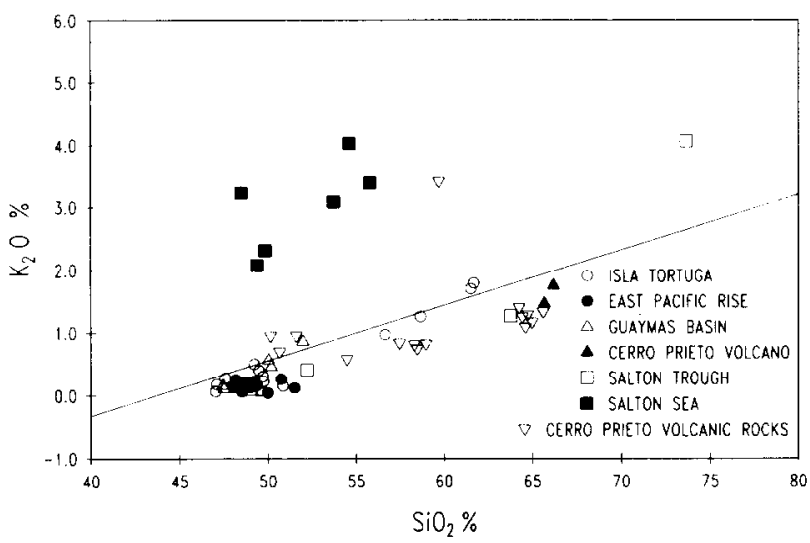

Figure 7. $\mathrm{SiO}_{2}$ vs $\mathrm{K}_{2} \mathrm{O}$ diagram.

Figura 7. Diagrama de $\mathrm{SiO}_{2}$ vs $\mathrm{K}_{2} \mathrm{O}$.

tendency, in which the values tend to decrease according to the $\mathrm{SiO}_{2}$ content. The opposite of this behavior is observed in the $\mathrm{K}_{2} \mathrm{O}$ and $\mathrm{Na}_{2} \mathrm{O}$ contents (fig. 6), which increase with the $\mathrm{SiO}_{2}$, whereas the $\mathrm{Al}_{2} \mathrm{O}_{3}$ (fig. 11) does not show any contrasting variation. A correlation can be observed between the local geochemistry and the regional pattern. These observations are the bases for the hypothesis that the conditions controlling the magma genesis under the Salton el campo geotérmico del mar de Salton (Rubinson et al., 1976) y el volcán Cerro Prieto (Reed, 1984).

La correlación de los datos geoquímicos en estos sitios no es sencillo, ya que involucra incertidumbre debido a que los datos pertenecen a diferentes fuentes. Más aún, en el caso de las rocas de subsuelo recuperadas en pozos geotermales, éstas han estado sometidas a procesos de alteración en su química de elementos mayores 


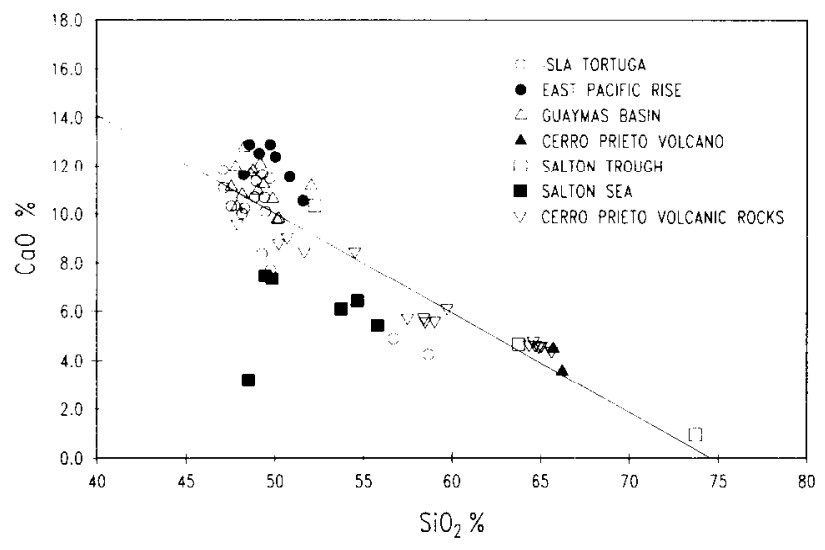

Figure 8. $\mathrm{SiO}_{2}$ vs $\mathrm{CaO}$ diagram.

Figura 8. Diagrama de $\mathrm{SiO}_{2}$ vs $\mathrm{CaO}$.

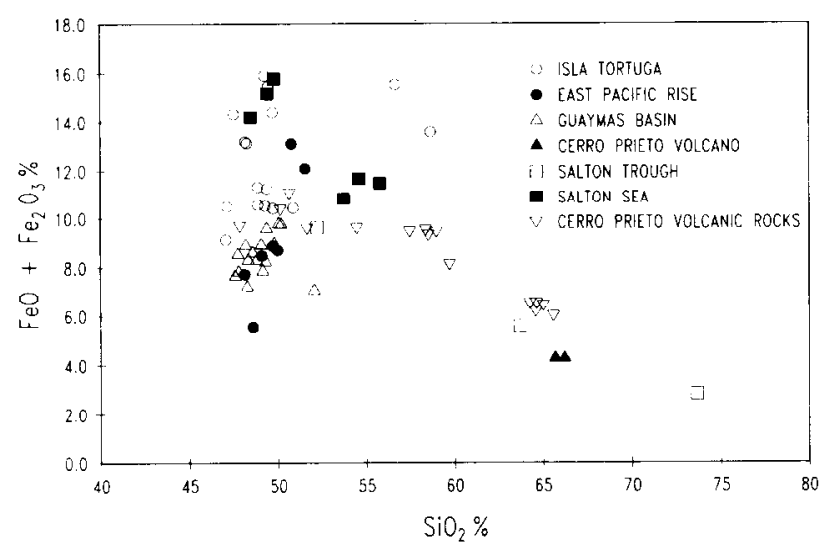

Figure 9. $\mathrm{SiO}_{2}$ vs $\mathrm{FeO}+\mathrm{Fe}_{2} \mathrm{O}_{3}$ diagram.

Figura 9. Diagrama de $\mathrm{SiO}_{2}$ vs $\mathrm{FeO}+\mathrm{Fe}_{2} \mathrm{O}_{3}$.

Trough, Cerro Prieto and Gulf of California are similar to those operating under active crustal spreading centers.

The basaltic rocks found in the Salton Sea area are olivine tholeiitic varieties (Robinson et al., 1976), classified as rocks with a low potassium content. These basalts occur as xenoliths.

The rocks from the Obsidian Buttes are rhyolite and the basaltic xenoliths are low in calcium (Elders, 1980) (fig. 8). The fresh rock samples of these rhyolites are very similar in composition to the rhyolites that have erupted
(Browne, 1977). Existen efectos de alteración en basaltos del golfo de California, que indican un enriquecimiento de $\mathrm{Fe}, \mathrm{Ti}, \mathrm{K}$ y una pérdida de $\mathrm{Mg}, \mathrm{Ca}, \mathrm{Si}$ (Terrel $e t$ al., 1979, en Perfit et al., 1982). Estos efectos de alteración involucran un error adicional cuando se hace la correlación de las rocas.

El diagrama de variación composicional (fig. 6) muestra que las rocas dentro de un marco regional (golfo de California, Cerro Prieto y mar de Salton) caen dentro de la clasificación de Cox et al. (1979): a) basaltos y 
over the East Pacific Rise islands, and have similar $\mathrm{Sr}^{87} / \mathrm{Sr}^{8 / 11}$ proportions (Robinson et al., 1975, in Elders, 1980). The Salton Sea subsurface basaltic rocks occur as sills or dikes and are also very similar to the tholeiitic basalts that erupted over the East Pacific Rise and the Gulf of California islands (Robinson et al., 1976).

The basalt-rhyolite bimodal assemblage of the Salton Sea geothermal field is believed to have originated from a partial melting of a peridotitic mantle in two stages, and which forms successive meltings of basaltic and rhyolitic composition (Robinson et al., 1976). The basaltic magma has been partially contaminated by continental crust material.

Isla Tortuga is located over a fracture zone in one of the spreading centers of the Gulf of California. There is a volcano located on the island that is composed of basalt-tholeiitic lava flows and vitric tuffs as well as tholeiitic andesites, but in lesser volume (Batiza, 1978). These rocks have a composition similar to those of Cerro Prieto and Guaymas Basin (figs. 6, 7, 8).

The Guaymas Basin rocks are classified as MORB basalts, pillow basalts, dolerites (diabases) and diabases with gabroic xenoliths (Perfit et al., 1982). In particular, these basalts have mineralogical and chemical characteristics that make them very similar to the ones studied from the East Pacific Rise. They are also very similar to those found at the GV-2 well at Cerro Prieto (subalkaline basalts of tholeitic composition).

The type of volcanism present in the regional framework, as can be observed in the major oxide diagrams, presents great similarity. This can be the basis to suppose that these rocks are the product of material originated from the peridutitic composition of a heterogeneous mantle, which has been affected by partial melting processes with continental crustal rocks until generating the bimodality of rhyolite-basalt rock types.

Figure 13 shows a simple petrogenetic model of basaltic magma generation in an active oceanic spreading center. These spreading centers are considered places where an elevation of the mantle occurs, due to an adiabatic decompression and the material starts to melt basalto-andesitas, b) andesitas, c) dacitas y d) riolitas.

Las gráficas de alcalinidad (figs. 6, 7, 8) muestran variedad en el tipo de vulcanismo presente en la región, pero se puede observar una tendencia lineal de rocas basálticas, en las que se incluyen las rocas de isla Tortuga, cuenca de Guaymas, dorsal del Pacífico Este, algunas rocas de subsuelo del campo Cerro Prieto y la depresión del Salton (cuyos valores de $\mathrm{SiO}_{2}$ se encuentran entre 45 y $55 \%$ ); rocas transicionales del tipo basalto-andesitas y andesitas, presentes básicamente en el campo geotérmico de Cerro Prieto (cuyos valores de $\mathrm{SiO}_{2}$ están entre 55-65\%); y las rocas de ambientes propiamente continentales del tipo dacitas $y$ riolitas, las cuales se presentan en el campo de Cerro Prieto (tanto en muestras subsuperficiales, como la expresión en superficie que es el volcán de Cerro Prieto) y los domos riolíticos (Obsidian Buttes) presentes en la depresión del Salton.

En el marco regional se puede observar que los óxidos como $\mathrm{CaO}$ (fig. 8), $\mathrm{FeO}$ (fig. 9), $\mathrm{MgO}$ (fig. 10) y $\mathrm{TiO}_{2}$ (fig. 12) mantienen una tendencia similar, ya que sus valores tienden a disminuir conforme se aumenta el contenido de $\mathrm{SiO}_{2}$. En contraste, el $\mathrm{K}_{2} \mathrm{O}$ y el $\mathrm{Na}_{2} \mathrm{O}$ (fig. 6) aumentan conforme se incrementa el $\mathrm{SiO}_{2}$, mientras que el $\mathrm{Al}_{2} \mathrm{O}_{3}$ (fig. 11) no muestra variación marcada. Lo anterior denota una correlación del patrón regional con el marco geoquímico local. Estas observaciones son la base que fundamenta la hipótesis de que las condiciones que controlan la génesis del magma bajo la depresión del Salton, Cerro Prieto y golfo de California, son similares a aquellas que operan bajo centros de dispersión activos de corteza.

Las rocas basálticas encontradas en el área del mar de Salton caen dentro de la variedad de tholeiitas de olivino (Robinson et al., 1976), clasificadas como rocas con bajos contenidos de potasio. Estos basaltos ocurren como xenolitos.

Las rocas ubicadas en el mar de Salton (Elders, 1980) provienen de rocas cuya composición es riolítica (Obsidian Buttes) y xenolitos basálticos incluidos en las primeras, las cuales 


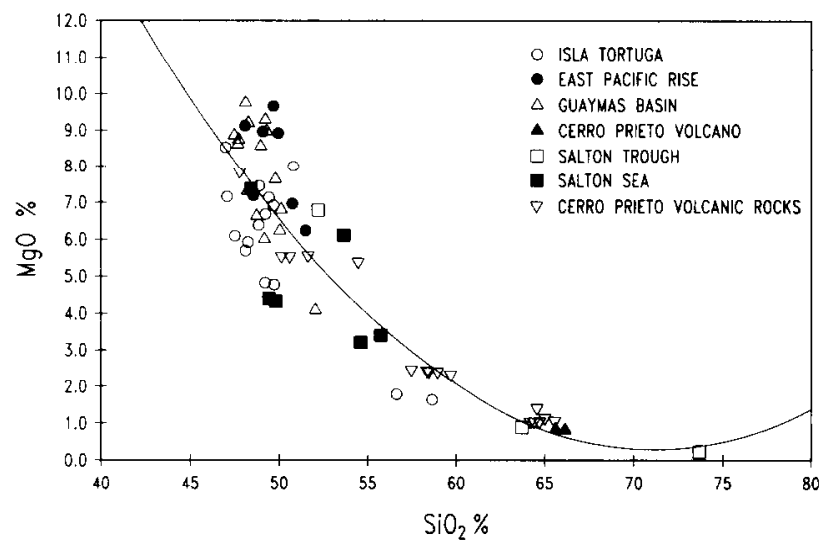

Figure 10. $\mathrm{SiO}_{2}$ vs $\mathrm{MgO}$ diagram.

Figura 10. Diagrama de $\mathrm{SiO}_{2}$ vs $\mathrm{MgO}$.

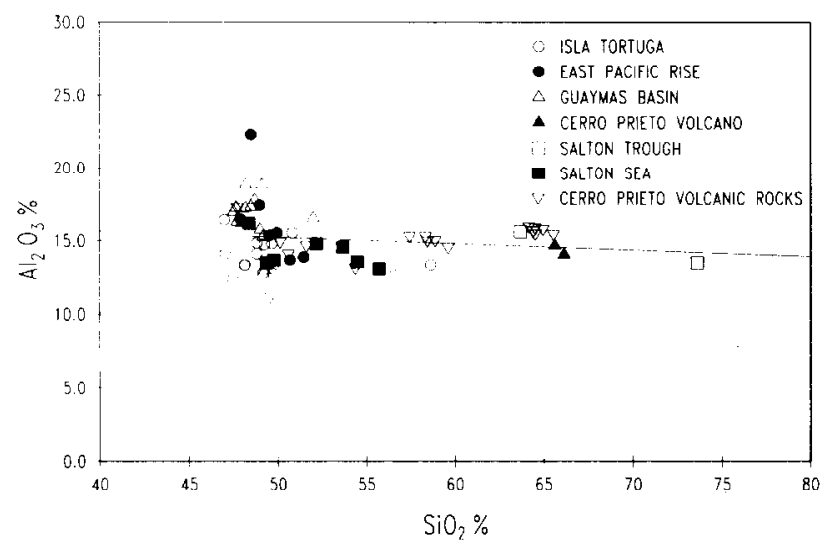

Figure 11. $\mathrm{SiO}_{2}$ vs $\mathrm{Al}_{2} \mathrm{O}_{3}$ diagram.

Figura 11. Diagrama de $\mathrm{SiO}_{2}$ vs $\mathrm{Al}_{2} \mathrm{O}_{3}$.

until basaltic magmas are produced (Wilson, 1989). The oceanic crust that generates the new material increases symmetrically on both sides of the spreading center axis, due to progressive cooling, until reaching $60-80 \mathrm{~km}$ in extension. The lithosphere base is distinguished by a $1200^{\circ} \mathrm{C}$ isotherm, which is a limit thermal layer that is subject to more chemical changes than mechanical ones.

The petrogenetic model for the intrusive bodies that has been proposed for the crustal spreading area in Cerro Prieto hy Quintanilla- presentan bajos contenidos de calcio (fig. 8). Las muestras frescas de estas riolitas son muy similares en composición a las riolitas que han erupcionado sobre las islas de la dorsal del Pacífico Este, y tienen proporciones similares de $\mathrm{Sr}^{87} / \mathrm{Sr}^{86}$ (Robinson et al., 1976, en Elders, 1980). Las rocas basálticas de subsuelo presentes en el mar de Salton ocurren en forma de diques o sills y son también muy similares a los basaltos tholeiiticos que erupcionaron sobre la dorsal del Pacífico Este y en las islas del golfo de California (Robinson et al., 1976). 


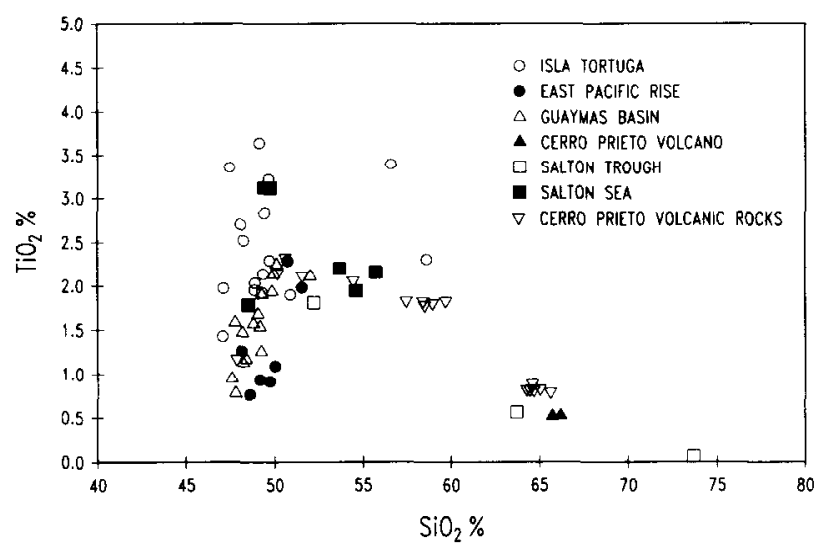

Figure 12. $\mathrm{SiO}_{2}$ vs $\mathrm{TiO}_{2}$ diagram.

Figura 12. Diagrama de $\mathrm{SiO}_{2}$ vs $\mathrm{TiO}_{2}$.

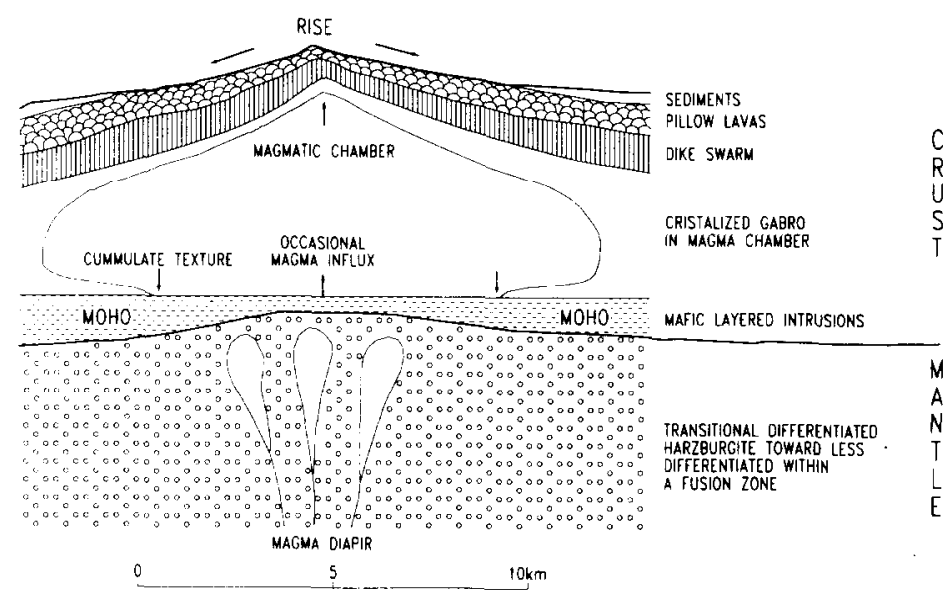

Figure 13. Hypothetical model of an oceanic spreading center that shows the development of the crust structure in response to the magmatic processes through the rise. (After Brown and Musset, 1981, in Hall, 1987.)

Figura 13. Modelo hipotético de un centro de dispersión oceánico, en el cual se muestra el desarrollo de la corteza en respuesta a los procesos magmáticos a través de la cresta. (Modificado de Brown y Musset, 1981, en Hall, 1987.)

Montoya and Suárez-Vidal (1994) differs from a merely oceanic center. Figure 14 shows that this region of continental basaltic magmatism is much more complex in terms of a petrogenetic explanation. This is due to several factors which can include the composition and mineralogy of
El conjunto bimodal basalto-riolita encontrado en las rocas del campo geotérmico del mar de Salton, se cree que ha sido formado por fusión parcial, en dos etapas, de un manto peridotítico, el cual forma mezclas sucesivas de composición basálticas y riolíticas (Robinson et 


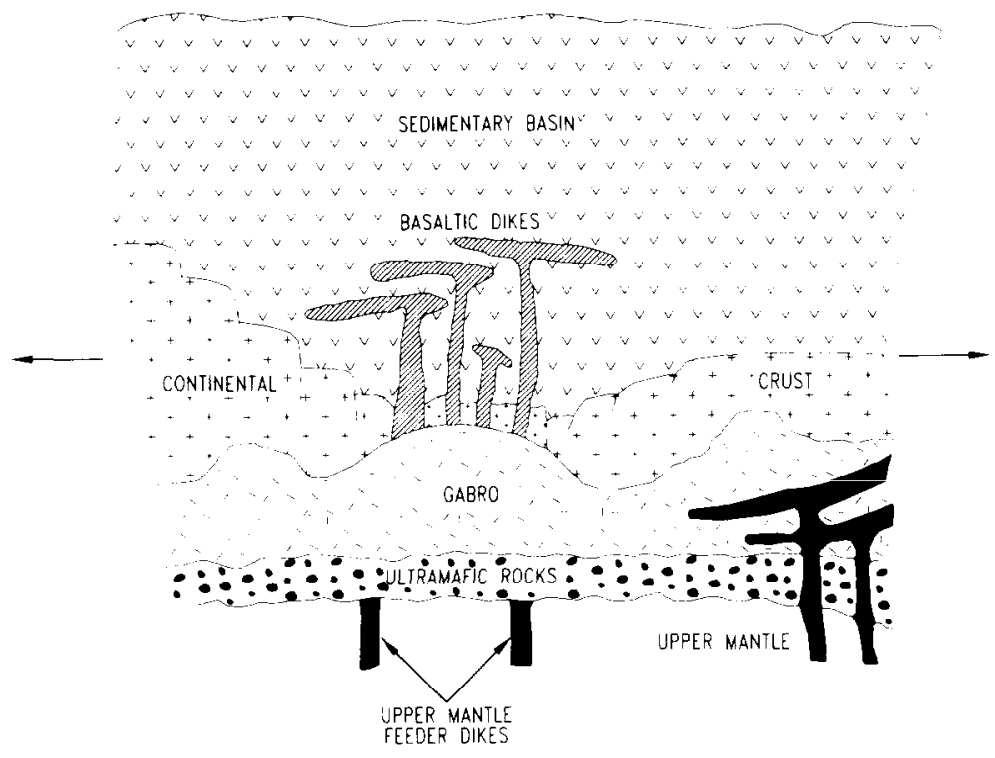

Figure 14. Conceptual model of the transitional spreading center of Cerro Prieto.

Figura 14. Modelo conceptual de un centro de dispersión transicional en Cerro Prieto.

the mantle source, the partial melting degree of the parent magma, the magma segregation depth, the fractioned crystallization extension and magma melting during its storage in the upper levels of the magmatic chamber.

The most important factor in the Cerro Prieto area is the partial melting of the magma, due to the interaction of the parent magma (of basic composition) with crustal continental rocks in its route to shallower depths. Figure 14 shows that dense magmas of basaltic composition are intruding as sill or dike complexes, which can provide an ideal environment for magma fractionation with continental crustal rocks (Patchett, 1980, in Wilson, 1989).

\section{CONCLUSIONS}

Based upon the petrological study of the subsurface rocks present in the Cerro Prieto geothermal field, as well as on the model proposed by Quintanilla-Montnya and SuárezVidal (1994) the conclusions are:

The geothermal field is associated with an active spreading center as a result of the al., 1976). Después de su formación, el magma basáltico ha sido parcialmente contaminado por material de corteza continental.

La isla Tortuga está ubicada sobre una zona de fractura en uno de los centros de dispersión del golfo de California. El volcán presente en ésta, está compuesto por flujos de lava basalto-tholeiiticos y tobas vitreas, además de la presencia en volúmenes menores de andesitas tholeiiticas (Batiza, 1978). Estas rocas se consideran en términos de su composición similares a las presentes en Cerro Prieto y la cuenca de Guaymas (figs. 6, 7, 8).

Las rocas de la cuenca de Guaymas, las cuales son basaltos del tipo MORB (mid-ocean ridge basalts), basaltos en almohadilla, doleritas (diabasas) y diabasas con xenolitos de gabro (Perfit et al., 1982). En particular, estos basaltos tienen características químicas y mineralógicas muy similares a los que se encuentran en la dorsal del Pacífico Este, y denotan similitud también con las rocas recuperadas del pozo GV-2 en Cerro Prieto, las cuales han sido identificadas como basaltos subalcalinos del tipo tholeiitico. 
tensional stress imposed by the Cerro PrietoImperial transform fault system, which acts as a structural linkage between the Gulf of California and San Andreas transform fault systems.

This kind of crustal spreading, as well as the volcanism associated with it, is not the same as a typical oceanic or continental center, due to the lithological variety. Figure 14 shows a hypothetical model proposed for the emplacement of intrusive bodies at depth.

The type of volcanism of the Cerro Prieto spreading center includes four types of rocks: a) basalts, b) basalt-andesites, c) andesites and d) dacites. The basaltic compositional rocks were found in two of the deepest wells in the field (GV-2 and M-203) and belong to the group of subalkaline basalts. The GV-2 well rocks (SE limit of the spreading center) are of the tholeiitic variety. The M-203 well rocks are transitional basalts to andesites. The chemical composition of these rocks has been affected by the partial melting of rocks from the continental crust during their intrusion to shallower depths, as sills or dikes. This is why the rocks are considered "contaminated". The observed textures in the rocks show evidence of a thermalcompositional disequilibrium during crystallization, which provokes the minerals to start reacting or mixing. Hydrothermal alteration patterns have affected the primary mineralogy.

Based on the geochemistry of rocks from the Gulf of California, it is clear that there is a wide variety of volcanism at a regional scale, and that there is a linear tendency from purely continental rocks (dacites and rhyolites) at Salton Sea and Cerro Prieto, which are seen in subsurface and surface samples (Cerro Prieto Volcano and the rhyolitic domes of Salton Trough), to typically oceanic basaltic rocks at Isla Tortuga, Guaymas Basin and the East Pacific Rise. The transitional rock types, between oceanic and continental, are basically located in the subsurface spreading center, considered transitional between the oceanics of the Gulf of California and the continental rocks located at the Salton Trough, California, USA.

\section{REFERENCES}

Barkcr, C.E. (1979). Vitrinite reflectance geothermometry in the Cerro Prieto geothermal
El tipo de vulcanismo que se presenta a nivel regional, como se puede observar en las gráficas de óxidos mayores, presenta gran similitud, lo cual puede ser base para suponer que éstas son producto de material proveniente de un manto heterogéneo de composición peridotítica, el cual se ha visto afectado por procesos de fusión parcial con rocas de corteza continental, hasta generar bimodalidad del tipo basalto-riolitas.

Un modelo simple petrogenético que ilustra la generación de magma basáltico en centros de dispersión oceánica activos se muestra en la fig. 13. Estos centros de dispersión se consideran sitios en los cuales existe elevación de material proveniente del manto, el cual se eleva debido a descompresión adiabática y comienza a mezclarse parcialmente hasta producir magmas basálticos (Wilson, 1989). La corteza oceánica que se genera en la cresta se incrementa simétricamente en grosor hacia los lados del eje de dispersión, debido a un enfriamiento progresivo, hasta alcanzar $60-80 \mathrm{~km}$ en extensión. La base de la litósfera se marca con la isoterma de los $1200^{\circ} \mathrm{C}$, la cual es una capa límite termal que refleja más que cambios químicos, cambios mecánicos.

El modelo petrogenético de los cuerpos intrusivos que se propone en este trabajo para la zona de dispersión de corteza en el área de Cerro Prieto, de acuerdo con QuintanillaMontoya y Suárez-Vidal (1994), difiere de un centro meramente oceánico. La fig. 14 muestra que esta región de magmatismo basáltico continental es más compleja en cuanto a su explicación petrogenética. Esto se debe a varios factores, entre los cuales se puede incluir: la composición y mineralogía de la fuente del manto, el grado de fusión o mezcla parcial del magma primario, la profundidad de segregación del magma, y la extensión de la cristalización fraccionada y los procesos de mezcla del magma durante el almacenamiento de éste en los niveles superiores de la cámara magmática.

Especificamente, el grado de fusión o mezcla parcial del magma es el factor más importante en el área de Cerro Prieto, debido a que el magma primario (de composición básica) ha interactuado con rocas de corteza continental en su ruta hacia profundidades más somcras. Como se observa en la fig. 14, el modelo 
system, Baja California, Mexico. M.Sc. thesis, Univ. of California, Riverside, 135 pp.

Batiza, R. (1978). Geology, petrology and geochemistry of Isla Tortuga, a recent tholeiitic island in the Gulf of California. Geol. Soc. Am. Bull., 89: 1309-1324.

Bielher, S., Kovach, R. and Allen, C.R. (1964). Geophysical framework of the northern end of the Gulf of California structural province. Symp. on Marine Geology of the Gulf of California, Tulsa, 1964, Vol. 3, pp. 114-156.

Browne, P.R.L. (1977). Occurrence and hydrothermal alteration of diabase, Heber geothermal field, Imperial Valley, California. IGPP Publ., 77/9, $70 \mathrm{pp}$.

Chase, D.S., Clover, R.C., Granell, R.B., Leggeive, R.M., Eppink, J., Tarman, D.W. and Goldstein, N.E. (1979). Precision gravity studies at Cerro Prieto. Proc. of the 1st Symp. on the Cerro Prieto Geothermal Field. Lawrence Berkeley Rep., No. 7098: 249-264.

Cox, K.G., Bell, J.D. and Pankhurst, R.J. (1979). The Interpretation of the Igneous Rocks. George Allen \& Unwin Publ. Co., 446 pp.

Elders, W.A. (1980). Magma hydrothermal systems in a sediment smothered crustal spreading regime: the Salton Trough. Symp. on magma-hydrothermal systems. EOS, 61(46): 1149.

Elders, W.A., Hoagland, J.R., Olson, E.R., McDowell, S.D. and Collier, P. (1978). A comprehensive study of samples from geothermal reservoirs: Petrology and light isotope geochemistry of twenty-three wells in the Cerro Prieto geothermal field, Baja California, Mexico. IGPP Rep., 78/26, $128 \mathrm{pp}$.

Elders, W.A., Bird, D.K. and Schiffman, P. (1984). Hydrothermal flow regime and magmatic heat source of the Cerro Prieto geothermal system, Baja California, Mexico. Geothermics, 13: 27-47.

Gilpin, B. and Lee, T.C. (1977). $\triangle$ microearthquake study in the Salton Sea geothermal area. Bull. Seis. Soc. Am., 68: 441-450.

Hall, A. (1987). Igneous Petrology. Longman Scientific Technical Co., 573 pp.

Hill, D.P., Mowinckel, P. and Peake, L.G. (1975). Earthquakes, active faults and muestra que magmas densos de composición basáltica se están elevando $o$ intrusionando como complejos de diques y sills, los cuales pueden proveer de un ambiente ideal para la fraccionación del magma dentro de un intervalo de presión restringido, en un ambiente altamente susceptible a contaminación con rocas de corteza continental (Patchett, 1980, en Wilson, 1989).

\section{CONCLUSIONES}

Con base en el estudio petrológico de las rocas de subsuelo presentes en el campo geotérmico de Cerro Prieto, así como en el modelo propuesto por Quintanilla-Montoya y Suárez-Vidal (1994), se derivan las siguientes conclusiones.

El campo geotérmico se encuentra asociado a un centro de dispersión de corteza activo, que es el resultado del esfuerzo tectónico tensional impuesto por las fallas transformes Cerro Prieto-Imperial, el cual actúa como eslabón estructural entre el sistema de fallas transformadas que opera en el golfo de California y el sistema de fallas San Andrés.

El tipo de dispersión de corteza, así como el vulcanismo asociado a ésta, difiere al de un centro meramente oceánico y/o continental, dcbido a la variedad litológica presente en éste, lo cual sugiere que dicho centro sea considerado transicional entre ambos, para lo cual el presente trabajo propone un modelo hipotético de emplazamiento de cuerpos intrusivos a profundidad (fig. 14).

El vulcanismo presente en el centro de dispersión Cerro Prieto incluye cuatro grupos: a) basaltos, b) basalto-andesitas, c) andesitas y d) dacitas. Las rocas de composición basáltica fueron encontradas en dos de los pozos más profundos (M-203 y GV-2), y pertenecen al grupo de basaltos subalcalinos. Las rocas del pozo GV-2 (límite al SE del centro de dispersión) son de la variedad tholeiitica y las del pozo M-203 son basaltos transicionales al grupo andesitas. La composición química de estas rocas se ha visto afectada debido al grado de fusión parcial que han tenido con rocas de corteza continental durante su intrusión o elevación a profundidades más someras, en forma de diques 
geothermal areas in the Imperial Valley, California. Science, 188: 1306-1308.

Johnson, C.E. and Hadley, D.M. (1976). Tectonic implications of the Brawley earthquake swarm, Imperial Valley, California. Bull. Seis. Soc. Am., 66: 1133-1144.

Lachenbruch, A.H., Sass, J.H. and Galanis, S.P. (1985). Heat flow in southernmost California and the origin of the Salton Trough. J. Geophys. Res., 90: 6709-6736.

Lawver, A.L. and Sclater, J.G. (1973). Heat flow measurements in the southern portion of the Gulf of California. Earth and Planetary Sci. Lett., North Holland Publ. Co., 12: 198-208.

Lawver, L.A. and Williams, D.L. (1979). Heat flow in the central Gulf of California. J. Geophys. Res., 84: 3465-3478.

Lee, T-C. and Cohen, L.H. (1979). Onshore and offshore measurements of temperature gradients in the Salton Sea geothermal area, Geophysics, 44(2): 206-215.

Lonsdale, P. and Spiess, F.N. (1979). A pair of young cratered volcanoes on the East Pacific Rise. J. Geol., 87: 157-173.

Perfit, M.R., Saunders, A.D. and Fornari, D.J. (1982). Phase chemistry, fractional crystallization and magma mixing in basalts from the Gulf of California. Deep Sea Drilling Project Leg 64. In: J.R. Curray, D.G. Moore et al., Initial Reports of the Deep Sea Project, Washington, DC, 64(2): 649-666.

Quintanilla-Montoya, A.L. y Suárez-Vidal F. (1994). Fuente de calor en el campo geotérmico de Cerro Prieto y su relación con la anomalia magnética Nuevo León. Geofísica Internacional, 33(4): 575-584.

Reed, M.J. (1984). Relationship between volcanism and hydrothermal activity at Cerro Prieto, Mexico. Trans. Geothermal Resources, Council 8, pp. 217-222.

Robinson, P.T., Elders, W.A. and Muffler, L.P.J. (1976). Quaternary volcanism in the Salton Sea genthermal field, Imperial Valley. Bull. Geol. Soc. Am., 87: 347-360.

Suárez-Vidal, F., Armijo, R., Morgan, G., Bodin, P. and Gastil, G. (1991). Framework of recent and cative faulting in northern Baja California. Am. Assoc. Petrol. Geol. Mem., 47: 285-300. o sills, por lo cual se les considera "rocas contaminadas". Las texturas observadas en estas rocas muestran evidencias de un desequilibrio térmico-composicional durante su cristalización, lo cual provoca que los minerales comiencen a mezclarse o a reaccionar, además de haber sido alteradas en su mineralogía primaria por patrones de alteración hidrotermal.

Con base en la información geoquímica obtenida para el vulcanismo presente en el golfo de California así como en Cerro Prieto y el área del mar de Salton, se puede observar, por medio de las gráficas de química de elementos mayores y elementos traza, que existe variedad en el tipo de vulcanismo presente en la región y que existe una tendencia lineal desde rocas puramente continentales de composición riolítica y dacítica (mar de Salton, California y Cerro Prieto), las cuales se presentan tanto en muestras subsuperficiales como en sus respectivas expresiones en superficie, representadas por el volcán de Cerro Prieto y los domos riolíticos presentes en la depresión del Salton, hasta rocas basálticas tipicamente oceánicas en las que se incluyen las rocas de isla Tortuga, cuenca de Guaymas y dorsal del Pacífico Este. Las rocas de tipo transicional entre un ambiente oceánico y uno continental, como son las secuencias basalto-andesitas y andesitas, se presentan básicamente en el área de Cerro Prieto, la cual se considera transicional entre el medio ambiente oceánico presente en el golfo de California y el medio continental presente en la depresión del Salton, California, EUA.

Traducido al español por los autores.

Von Herzen, R.P. (1963). Geothermal heat flow in the Gulf of California and Aden. Science, 140: 1207-1208.

White, D.E. (1973). Characteristics of geothermal resources. In: P. Krueger and C. Otte (eds.), Genthermal Fnergy. Stanford Univ. Press, Stanford, pp. 69-94.

Williams, H., Turner, F.J. and Gilbert, C.M. (1982). Petrography, 2nd edition. W.H. Freeman \& Co., New York, $626 \mathrm{pp}$.

Wilson, M. (1989). Igneous Petrogenesis. Unwyn Hyman Co., 466 pp. 